\title{
MARKET PERCEPTION OF BANK RISK AND SECURITIZATION IN SPAIN*
}

\author{
Ana IGLESIAS-CASAL ${ }^{1}$, Maria Celia LÓPEZ-PENABAD², \\ Carmen LÓPEZ-ANDIÓN ${ }^{3}$, Jose Manuel MASIDE-SANFIZ ${ }^{4}$ \\ ${ }^{1,3}$ Department of Quantitative Economics, University of Santiago de Compostela, \\ Avda. do Burgo, s/n, 15782, Santiago de Compostela, Spain \\ ${ }^{2,4}$ Department of Finance and Accounting, University of Santiago de Compostela, \\ Avda. do Burgo, s/n, 15782, Santiago de Compostela, Spain \\ E-mails: ${ }^{1}$ ana.iglesias.casal@usc.es; ${ }^{2}$ celia.lopez@usc.es (corresponding author); \\ 3carmen.lopez.andion@usc.es; josemanuel.maside@usc.es
}

Received 14 January 2013; accepted 20 May 2013

\begin{abstract}
This paper examines the systematic risk in those banks that participated as issuers of securitization transactions in the Spanish market. Using event study methodology and allowing systematic risk to change gradually within the event window, this paper provides empirical evidence that securitization has a positive impact on Spanish bank's systematic risk (beta) from the beginning to the end of the event window. Additionally, we assess how much of the beta effect is due to volatility and how much to market correlation. The increase in beta is solely due to an increase in banks' correlations, improving portfolio diversification. The empirical results presented in this paper show important informative implications for the different agents related to banks. This creates a challenge for financial regulation, which has typically focused on individual institutions.
\end{abstract}

Keywords: securitization, systematic risk, systemic risk, event study, financial stability, transfer of risk, mortgage-backed securities, assets-backed securities, banks, Spain.

JEL Classification: G28, G21.

\section{Introduction}

Securitization has been the object of harsh criticism because of its links to the origin of the financial crisis. Problems of asymmetric information and moral hazard, derived from the dissociation of securitized asset portfolios from issuing banks, might give rise to loans of lower credit quality. It is along these lines that several studies have served to augment the lack of confidence in this process. Among others, Keys et al. (2010) indicate that securitized assets are more likely to default than unsecuritized assets with similar characteristics due to a lack of banking control. Purnanandam (2009) highlights

\footnotetext{
* This study was carried out with financing help from the Applied Financial Evaluation Research Group, http://www.usc.es/valfinap.
} 
that the banks that securitized using the "originate to distribute" model tend to create lower quality mortgages. Similarly, Calmes and Teóret (2010) indicate that off-balancesheet activities tend to increase the bank's systemic risk. Specifically, Fahri and Tirole (2009) point to securitization as a mechanism that reinforces financial leverage and increases systemic risk. Further, some authors, such as Douglas and Raghuram (2009), hold that the misallocation of resources by the financial sector within the real estate sector were responsible for the crisis in the USA. These resources were, in the main, obtained through securitization. The most commonly mentioned problems of securitization are its complexity, off-balance sheet treatment, asymmetric information problems, agency problems and relatively high transaction costs (Pinto 2014).

The seriousness and the sweeping nature of the present crisis indicate that risk-transfer activities have led to increased risks in at least some parts of the financial system. Banks have traditionally eliminated very few risks from their balance sheets. However, in recent years, they have increased their risk-transfer activities and one of the mechanisms by which they do this is securitization.

This is the context within which the study has been framed. It attempts to empirically analyse the systematic risk generated by those entities that issue securitized assets and how this affected systemic risk in the Spanish market between 1993 and 2010. We believe that this work complements and enlarges upon other empirical studies in the field for various reasons.

First, the analysis focuses on the Spanish market. In spite of the fact that the Spanish securitization market is highly significant, research has tended to centre on the factors that promote securitization (Cardone-Riportella et al. 2010), on the effects of securitization on the issuing banks' share prices (Martínez-Solano et al. 2009; López-Penabad et al. 2015) or on the issuing banks' solvency (López-Andión et al. 2015). There are no empirical studies that analyse how securitization influences systematic and systemic risk within the Spanish market, as will be seen in the following section.

What makes this study especially innovative are; the peculiarities of the Spanish securitization market i.e. that which sets it apart in terms of legislation, the fact that the Spanish model is well established and simple when it comes to the structure of securitization, the nature of the traditional Spanish banking model and the high rate of retentions in the equity tranche ${ }^{1}$.

Further, the time frame used in the study is extensive and takes in the period when securitization first began in Spain in 1993, and goes up to 2010 and thus captures the last three years of the crisis.

We believe that our study provides an original contribution to the literature that looks at the effects of securitization on systematic and systemic risk. The geographical focus

\footnotetext{
${ }^{1}$ Securitization is a mechanism that facilitates the stratification of credit risk. The bonds are issued in different series with a specific subordinate structure. In the lower part of this structure are the series containing the lowest credit quality products, the equity tranche, which is normally retained by the issuer in order to provide the required credit enhancement level to the higher tranches, "mezzanine" and "senior".
} 
of the work is different and looks at distinct banking structures governed by a different kind of legislation. Further, the time-frame used is broad in scope and takes in the years of the crisis. Given that the predominant securitization model in the Spanish market has been "originate to hold", it would seem likely that the exposition to global risk of the issuing entities in this study increases, unless the final portfolio losses exceed those of the first loss tranche (equity tranche). Further, the effect of securitization will be conditioned by the reinvestment strategy adopted by the issuing entities. When there is a perceivable increase in the systematic risk in the issuing entities, it becomes of interest to analyse whether or not this increase is due to a greater correlation between banking entities or an increase in specific risk. Thus, it becomes possible to discover if there has been an increase in systemic risk, which the current crisis would seem to suggest. The rest of this study is set out as follows; the following section contains a review of the existing literature. This is followed by a section which describes the data-base used and the methodology adopted. The following section gives and interprets the results of the econometric analysis carried out. The final section sets out the main conclusions.

\section{Review of the existing literature}

The securitization of assets is a financial operation by which a set of illiquid assets is transformed into a series of securities which are then placed in the marketplace (securitization bonds) and guaranteed by a series of specific payment flows. At the same time therefore, depending on the process via which it is carried out, securitization is, to a greater or lesser extent, a mechanism for transferring risk. Hence, securitization has an important effect on the risk profile and the financial soundness of the issuing entities and on the financial system as a whole.

We first analyse the direct impact of securitization on the risk incurred by the issuing entity, that is, the amount of risk which is transferred to the market. Studies that highlight the stabilizing effect of securitization indicate that the banks' exposure to overall risk is likely to be reduced if the tail risk of the senior tranches transferred to external investors exceeds the default risk of first loss tranches which are typically retained by the bank. This produces a transfer of risk from the issuing entity to the investors (Jiangli et al. 2007). Other studies that highlight the fragility of the securitization mechanism, demonstrate that the major part of the default risk remains within the bank's first loss tranche as a sign of quality for external investors (DeMarzo 2005; Instefjord 2005).

Secondly, this study analyses the indirect impact of securitization on the originator entity. The effect of securitization will depend on the strategy adopted by the originator when reinvesting the resulting liquidity. This impact depends on the investment policy adhered to and is defined by the risk transformation that the bank's portfolio undergoes (Leland 2007). In this sense, the reinvestment process, for those in which the stabilizing nature of securitization is of foremost importance, might give rise to improved diversification on the entity's balance sheet if there is subsequent investment in new assets which are not closely related to the rest of the assets in the portfolio. In contrast, for those that stress the debilitating nature of securitization, the effect on the 
entity's financial stability depends on the level of risk of the new assets which is in turn determined, to a large extent, by the level of market competitiveness (Instefjord 2005). Hence, if the liquidity obtained via securitization is used to increase the amount of total assets, or the repurchase of shares and the payment of higher dividends for example, this might generate even greater leverage, debilitating the financial stability of the entity (Shin 2009; Leland 2007).

Taking the market as a whole, credit risk transfer might increase bank risk in a systemic sense in spite of the fact that individual bank risk does not increase. Securitization allows the banks to shed specific risk, risk which is associated with lending. However, a collateral effect might be that the banks become more closely correlated to one another. A situation of this type might increase the risk of systemic crises in the financial system (Elsinger et al. 2006; Acharya, Yorulmazer 2007; Wagner 2009) given that it increases the likelihood that banks incur losses jointly. In addition, securitization normally exposes banks to greater funding risk. In the main, these risks are systemic in nature as recent events have shown, given that the markets of securitized assets and the markets that fund these assets are going through difficulties.

The empirical studies that analyse the effects of securitization on the risk profile are in agreement that there is an increase in the systematic risk for the issuing entities (Franke, Krahnen 2006; Hänsel, Krahnen 2007; Udhe, Michalak 2010; Nijskens, Wagner 2011; Le et al. 2015). These works suggest that the effect of the reduction in risk derived from securitization is absorbed by the reinvestment of the liquidity in projects with greater risk and that, essentially, this reduction is determined by the stratification technique used for the issue of securitization. Therefore, an increasing post-event beta must be the consequence of the fact that the first loss tranches are more likely to incur defaults than the senior tranches, which carry less risk and have been transferred to external investors. In addition, Nijskens and Wagner (2011) show that the increase in beta is due solely to an increase in banking correlations.

As stated above, the object of this work is to study the systematic risk of the issuing entities in Spain and how this might be transformed into systemic risk. In the Spanish market, we know that the predominant model of securitization has been "originate to hold" 2 , which only produces one real transfer of risk when the final loss of the portfolio exceeds the first loss tranche. Hence, we might expect an increase in the systematic risk of the issuing entities. Nevertheless, it should not be forgotten that there is an indirect effect derived from the reinvestment of the new funds that have been captured that might be allocated to assets with a lower correlation with the issuing entity's portfolio, improving diversification, or, just the reverse, they might be destined to acquire assets of lower credit quality. In this sense, and particularly in the last few years when the supply of credit has expanded, securitization might have given rise to an increase in the volume of lower quality of credit. Not only would this have led to the generation of products of lower credit quality, but it would also have undermined the banks' financial

\footnotetext{
${ }^{2}$ Among others, Catarineu and Pérez (2008) and Cardone et al. (2010).
} 
soundness, and increased their risk. This study also separates the systematic risk into two components; volatility and market correlation. This makes it possible to see how each of these evolves and to determine the potential transformation of systematic risk into systemic risk.

\section{Data and econometric method}

\subsection{Data and sources}

Our database is made up of 468 issues of mortgage-backed securities (MBS) and asset backed securities (ABS) which were carried out in Spain between 1993 and July 2010. The data was obtained by referring to the National Stock Market Commission (CNMV acronym in Spanish), the Association of Financial Asset Intermediaries for the Spanish market for corporate debt (AIAF-acronym in Spanish), and the existing Spanish asset securitization management companies' web pages. In addition, there is data that corresponds to the daily share prices at the close of trading for 14 of the banks ${ }^{3}$ that have been the originators in the issue of securitization. This data was obtained from the web page for Spanish markets (BME-initials in Spanish). In our data base we have counted up to 25 banks that have acted as originators, but have only been able to obtain closing prices for those entities that have been quoted on the stock exchange for at least a minimum period of time ${ }^{4}$. Hence, our database is limited to 185 emissions of traditional securitization, with an average volume of 1090 Million $€$, corresponding to 14 quoted issuing banks (Table 1). Of these banks, the most active have been BBVA with 30 issues, followed by Santander with 27 and Bankinter with 23. The largest securitization issues, in terms of volume, were also originated by these three banks, and together with the Banco Popular and Banesto, they were responsible for issuing 55\% of all operations with mortgage collateral.

As indicators of the market portfolio the study uses data from the daily close-of-trading figures for the Ibex-35 and the IGBM for the period being studied.

\subsection{Econometric methodology}

The main goal of the study is to analyse the effects of securitization on the systematic risk of the issuing banks measured using the beta coefficient. In the classical CAPM model, beta is given by the following expression:

$$
\beta_{i}=\frac{\operatorname{Cov}\left(\mathrm{R}_{i}, \mathrm{R}_{m}\right)}{\sigma_{m}^{2}}=\rho_{i, m} \frac{\sigma_{i}}{\sigma_{m}},
$$

where $\mathrm{R}_{i}$ and $\mathrm{R}_{m}$ represent the returns of the banks' stocks and the market respectively;

\footnotetext{
${ }^{3}$ The banks for which stock market quotes are available are shown in Table 1.

${ }^{4}$ Since the savings banks are not quoted on the stock exchange it is not possible to obtain an indicator as to how their securitization activity is affecting systematic risk, even though it is an important proportion of all securitization in Spain. However, given the characteristics of these entities, and that little of their activity takes place outside Spain, there are good reasons to believe that the return of these entities is similar to that of the quoted banks.
} 
Table 1. Descriptive statistics. Issuing volume by bank in the sample (millions of $€$ )

\begin{tabular}{lcccccc}
\hline & $\mathrm{T}$ & Total volume & Mean & $\begin{array}{c}\text { Standard } \\
\text { deviation }\end{array}$ & Minimum & Maximum \\
\hline Total securitizations & 185 & 201000 & 1090 & 1180 & 17.9 & 8500 \\
\hline Banks & & & & & & \\
\hline Banco de Andalucía & 8 & 2180 & 272 & 96.2 & 72.8 & 403 \\
\hline Banesto & 10 & 13700 & 1370 & 676 & 545 & 2300 \\
\hline Bankinter & 23 & 24200 & 1050 & 477 & 320 & 2040 \\
\hline BBVA & 30 & 64000 & 2130 & 1860 & 28 & 8500 \\
\hline Banco de Castilla & 7 & 980 & 140 & 66.7 & 34 & 221 \\
\hline Banco de Crédito Balear & 7 & 401 & 57.3 & 25.8 & 26.5 & 103 \\
\hline Banco de Galicia & 7 & 836 & 119 & 54.5 & 26.8 & 200 \\
\hline Banco Guipuzcoano & 13 & 3050 & 235 & 140 & 60.1 & 597 \\
\hline Banco Pastor & 13 & 7270 & 559 & 262 & 150 & 1000 \\
\hline Banco Popular & 12 & 20700 & 1720 & 1500 & 243 & 6000 \\
\hline Banco de Sabadell & 14 & 14400 & 1030 & 353 & 500 & 1740 \\
\hline Banco de Santander & 27 & 44300 & 1640 & 966 & 262 & 3590 \\
\hline Banco de Valencia & 7 & 4320 & 617 & 334 & 55 & 979 \\
\hline Banco de Vasconia & 7 & 807 & 115 & 72.4 & 17.9 & 220 \\
\hline
\end{tabular}

$\rho_{i, m}$ the Pearson's correlation coefficient between the return of the asset and that of the market; and $\sigma_{i}$ and $\sigma_{m}$ the standard deviation of the stock's return and that of the market respectively. Therefore, the changes in beta depend on changes in the standard deviation of the return of the banks' stocks in relation to the market and the correlation between the stock and market return.

In line with Franke and Krahnen (2006), we assume that losses in the bank's portfolio have a direct impact on the current market value of the bank's stocks. As a consequence, a higher standard deviation of default losses incurred by the bank translates into a higher standard deviation of its stock returns. Hence, when the correlation between market return and the banks' stock return remains constant, a higher standard deviation in stock return produces an increase in systematic bank risk. It is also assumed that an increase in the banks' loan portfolio granularity implies a greater correlation between the bank and the market. Therefore, an increase in granularity will give rise to greater diversification in the portfolio which will become more closely aligned to that of the market, increasing the correlation between market return and the stocks held in portfolio. In addition, it should be remembered that any variation in the systematic risk depends on the bank's pre-event risk level compared to the market level. Hence, when the level of pre-event systematic risk is lower (greater) than the market level, an increase in the correlation with market return might lead to an increase (decrease) in the banks' systematic risk.

Following Uhde and Michalak (2010), the model proposed for this analysis is based on the classical CAPM model and uses dummy variables to reflect the fact that an entity's 
systematic risk might change on or around the date when the event occurs or becomes known and also after the given temporal interval. Hence, the following basic regression model is proposed:

$$
\mathrm{R}_{i, t}=\beta_{i, 0}+\beta_{i, 1} \mathrm{R}_{m, t}+\beta_{i, 1}^{\Delta \text { event }} \mathrm{D}_{1, t} \mathrm{R}_{m, t}+\beta_{i, 1}^{\Delta \text { after }} \mathrm{D}_{2, t} \mathrm{R}_{m, t}+\eta_{i, t},
$$

where $\mathrm{R}_{i, t}$ and $\mathrm{R}_{m, t}$ are the daily returns on banks' stocks $i$ and the market portfolio $m$ at a trading day $t$. These returns are obtained as the first difference of the logarithm of stocks prices. Ibex-35 is deemed to be the market portfolio index. The event windows or intervals used are $[-30,+30],[-20,+20],[-10,+10]$ and $[-5,+5]$ days, and the regressions are carried out using 241 data symmetrically moving around the event day. $t_{0}$ is the date of the event and is when the securitization is registered with the CNMV. $\mathrm{D}_{1, t}$ and $\mathrm{D}_{2, t}$ are the dummy variables. $\mathrm{D}_{1, t}$ takes a value of 1 if $\mathrm{T}_{1} \leq t \leq \mathrm{T}_{2}$, and $\mathrm{T}_{1}$ and $\mathrm{T}_{2}$ represent the start and end of the window, and takes a value of 0 otherwise. $\mathrm{D}_{2, t}$ takes a value of 1 if $t>\mathrm{T}_{2}$ and 0 for the rest.

The methodology, proposed by Cyree and DeGennaro (2002), allows the analysis to reflect that the change in the banks' systematic risk does not necessarily follow a linear function. Therefore, in order to allow the systematic risk to vary gradually during the period of the event and to leave the window at higher or lower levels, betas were established that vary as follows:

$$
\begin{gathered}
\beta_{i, 1}^{\Delta \text { event }}=\beta_{i, 2}\left(\mathrm{~T}_{1}-\mathrm{t}\right)\left(\mathrm{t}-\mathrm{T}_{2}\right)+\beta_{i, 3}\left(\mathrm{t}-\mathrm{T}_{1}\right)+\mathrm{v}_{i, t} ; \\
\beta_{i, 1}^{\Delta \text { after }}=\beta_{i, 3}\left(\mathrm{~T}_{2}-\mathrm{T}_{1}\right)+\xi_{i, t} .
\end{gathered}
$$

Such that $\beta_{i, 1}^{\Delta \text { event }}$ measures the marginal change of systematic risk within the event window, allowing $\beta_{i, 1}$ to follow a continuous concave, convex or linear function. The parameter $\beta_{i, 2}$ indicates the functional form of the change in systematic risk during the event window. If $\beta_{i, 2}$ is negative (positive), the change in the systematic risk is a convex (concave) function during the window. If $\beta_{i, 2}$ is equal to zero, the change is a linear function.

Equation (4) describes $\beta_{i, 1}^{\Delta \text { after }}$ as the marginal change of the systematic risk within the post-event period. Hence, $\beta_{i, 1}$ might leave the window at a higher or a lower level compared to the pre-event period depending on whether $\beta_{i, 3}$ is greater or lesser than zero. $\beta_{i, 1}$ might also be constant if $\beta_{i, 2}$ and $\beta_{i, 3}$ are zero.

By substituting (3) and (4) into (2) the following regression model is obtained:

$\mathrm{R}_{i, t}=\beta_{i, 0}+\beta_{i, 1} \mathrm{R}_{m, t}+\beta_{i, 2}\left(\mathrm{~T}_{1}-\mathrm{t}\right)\left(\mathrm{t}-\mathrm{T}_{2}\right) \mathrm{D}_{1, t} \mathrm{R}_{m, t}+\beta_{i, 3}\left[\left(\mathrm{t}-\mathrm{T}_{1}\right) \mathrm{D}_{1, t}+\left(\mathrm{T}_{2}-\mathrm{T}_{1}\right) \mathrm{D}_{2, t}\right] \mathrm{R}_{m, t}+\varepsilon_{i, t}$.

On allowing time varying betas during and after the event period introduces the error term $\varepsilon_{\mathrm{i}, \mathrm{t}}$ as a function of market return, with a) $\varepsilon_{i, t}=\eta_{i, t}$ over the period of the pre-event estimation, b) $\varepsilon_{i, t}=\eta_{i, t}+v_{i, t} \mathrm{R}_{m, t}$ during the window and c) $\varepsilon_{i, t}=\eta_{i, t}+\xi_{i, t} \mathrm{R}_{m, t}$ within the post-event period. In this work it is assumed that the variance of the error term $\varepsilon_{i, t}$ is not constant and that the variability is captured through a GARCH $(1,1)$ : 


$$
\mathrm{h}_{i, t}=\alpha_{i, 0}+\alpha_{i, 1} \varepsilon_{i, t}^{2}+\alpha_{i, 2} \mathrm{~h}_{i, t-1},
$$

where $\mathrm{h}_{i, t}=\mathrm{E}\left(\varepsilon_{i, t}^{2} / \Omega_{t-1}\right)$ is the conditional variance of $\varepsilon_{i, t}$.

Table 2 shows that there are clusters of volatility. This result is obtained by analysing the significance of the first order autocorrelation coefficients of the squared and absolute values of bank's returns using Ljung-Box statistics. Hence, it was possible to confirm the need to model the conditional variance together with the equation for the conditional mean to obtain the most efficient estimators. In addition, it can be observed that the series of returns are stationary (ADF test) and do not follow a normal distribution (JB test).

Table 2. Descriptive statistics of bank stock returns

\begin{tabular}{|c|c|c|c|c|c|c|c|c|c|c|c|}
\hline Banks & S & $\mathrm{K}$ & JB & p-val & $\mathrm{ADF}$ & p-val & $\mathrm{Q}\left(\mathrm{r}_{\mathrm{t}}^{2}\right)$ & $\mathrm{p}$-val & $\mathrm{Q}\left(\left|\mathrm{r}_{\mathrm{t}}\right|\right)$ & p-val & N. obs \\
\hline $\begin{array}{l}\text { Banco de } \\
\text { Andalucía }\end{array}$ & -0.4 & 24.3 & 65793.9 & 0.0 & -63.4 & 0.0 & 176.5 & 0.0 & 278.7 & 0.0 & 3489 \\
\hline Banesto & -0.9 & 27.2 & 72779.8 & 0.0 & -56.4 & 0.0 & 129.2 & 0.0 & 319.0 & 0.0 & 2977 \\
\hline Bankinter & 0.3 & 7.6 & 2525.5 & 0.0 & -50.7 & 0.0 & 271.3 & 0.0 & 227.1 & 0.0 & 2752 \\
\hline BBVA & 0.2 & 10.0 & 8157.9 & 0.0 & -58.5 & 0.0 & 185.7 & 0.0 & 367.9 & 0.0 & 3972 \\
\hline $\begin{array}{l}\text { Banco de } \\
\text { Castilla }\end{array}$ & 0.3 & 13.2 & 11832.0 & 0.0 & -34.1 & 0.0 & 318.8 & 0.0 & 225.7 & 0.0 & 2727 \\
\hline $\begin{array}{l}\text { Banco de } \\
\text { Crédito } \\
\text { Balear }\end{array}$ & 0.2 & 18.5 & 27042.3 & 0.0 & -30.9 & 0.0 & 37.5 & 0.0 & 97.5 & 0.0 & 2702 \\
\hline $\begin{array}{l}\text { Banco de } \\
\text { Galicia } \\
\end{array}$ & 0.4 & 14.1 & 13895.8 & 0.0 & -35.4 & 0.0 & 232.1 & 0.0 & 266.0 & 0.0 & 2700 \\
\hline $\begin{array}{l}\text { Banco } \\
\text { Guipuzcoano }\end{array}$ & 0.8 & 12.2 & 10802.6 & 0.0 & -58.6 & 0.0 & 122.0 & 0.0 & 240.5 & 0.0 & 2975 \\
\hline Banco Pastor & 0.3 & 8.6 & 3707.8 & 0.0 & -51.2 & 0.0 & 81.1 & 0.0 & 147.8 & 0.0 & 2765 \\
\hline $\begin{array}{l}\text { Banco } \\
\text { Popular } \\
\text { Español }\end{array}$ & 0.1 & 10.5 & 7522.4 & 0.0 & -55.0 & 0.0 & 92.4 & 0.0 & 228.8 & 0.0 & 3213 \\
\hline $\begin{array}{l}\text { Banco } \\
\text { Sabadell } \\
\end{array}$ & 0.6 & 13.4 & 9045.1 & 0.0 & -42.0 & 0.0 & 55.8 & 0.0 & 44.5 & 0.0 & 1981 \\
\hline $\begin{array}{l}\text { Banco } \\
\text { Santander }\end{array}$ & 0.4 & 13.7 & 16607.7 & 0.0 & -59.1 & 0.0 & 299.0 & 0.0 & 524.5 & 0.0 & 3462 \\
\hline $\begin{array}{l}\text { Banco de } \\
\text { Valencia }\end{array}$ & 0.5 & 9.3 & 2976.4 & 0.0 & -43.7 & 0.0 & 89.7 & 0.0 & 161.2 & 0.0 & 1733 \\
\hline $\begin{array}{l}\text { Banco de } \\
\text { Vasconia }\end{array}$ & 0.2 & 16.6 & 20328.8 & 0.0 & -58.3 & 0.0 & 298.5 & 0.0 & 279.5 & 0.0 & 2654 \\
\hline
\end{tabular}

Notes: $\mathrm{S}$ is the Skewness and $\mathrm{K}$ is the Kurtosis; JB denotes the Jarque-Bera normality test; ADF is the Augmented Dickey-Fuller unit root test which lags for the auxiliary equation are determined with the Schwarz criterion; $\mathrm{Q}\left(\mathrm{r}_{\mathrm{t}}^{2}\right)$ and $\mathrm{Q}\left(\left|\mathrm{r}_{\mathrm{t}}\right|\right)$ are the Ljung-Box tests for the first order autocorrelation of the squares and the absolute values of the return respectively. The data used corresponds to the period between January 1994 and October 2010. 
Further, following equation (1), we analyse which parts of the banks' beta correspond to their correlation with the market and which to the relative standard deviation. Subsequently, we estimate whether the possible change in the systematic risk has led to a change in bank correlations.

The aim of this procedure is to normalize the stocks and market returns by using their respective standard deviations. By doing this and following Nijskens and Wagner (2011), we obtain a series with a standard deviation of one. From equation (1) we reach the stage at which the estimated regression coefficient of these transformed returns equals the correlation of the original series. This normalization can be implemented in the modified regression model, equation (5), where the symbol $\sim$ represents the transformed series:

$\tilde{\mathrm{R}}_{i, t}=\rho_{i, 0}+\rho_{i, 1} \tilde{\mathrm{R}}_{m, i, t}+\rho_{i, 2}\left(\mathrm{~T}_{1}-\mathrm{t}\right)\left(\mathrm{t}-\mathrm{T}_{2}\right) \mathrm{D}_{1, t} \tilde{\mathrm{R}}_{m, i, t}+\rho_{i, 3}\left[\left(\mathrm{t}-\mathrm{T}_{1}\right) \mathrm{D}_{1, t}+\left(\mathrm{T}_{2}-\mathrm{T}_{1}\right) \mathrm{D}_{2, t}\right] \tilde{\mathrm{R}}_{m, i, t}+\varepsilon_{i, t}$,

where:

$$
\tilde{\mathrm{R}}_{i, t}=\left\{\begin{array}{l}
\mathrm{R}_{i, t} / \sigma_{i, t<T_{1}} \text { if } t<\mathrm{T}_{1} \\
\mathrm{R}_{i, t} / \sigma_{i, t \geq T_{1}} \text { if } t \geq \mathrm{T}_{1}
\end{array} \text { and } \tilde{\mathrm{R}}_{m, i, t}=\left\{\begin{array}{l}
\mathrm{R}_{m, i, t} / \sigma_{m, i, t<T_{1}} \text { if } t<\mathrm{T}_{1} \\
\mathrm{R}_{m, i, t} / \sigma_{m, i, t \geq T_{1}} \text { if } t \geq \mathrm{T}_{1}
\end{array} .\right.\right.
$$

In the computation of the normalized variables, we allowed standard deviations to differ before and after the beginning of the window $\left(\mathrm{T}_{1}\right)$.

The results of the estimation of equation (7), together with the equation for the conditional variance, allow us to see the beta correlation component and its possible variation as a consequence of securitization.

Finally, in order to evaluate how much of the variation in the beta is due to the correlation effect (a change in $\rho_{i, m}$ ) and how much to the bank's standard deviation relative to the market (a change in $\frac{\sigma_{i}}{\sigma_{m}}$ ), we derive an expression for the change in the relative standard deviation. The periods immediately prior and subsequent to the event window are termed 0 and 1 . Therefore, the systematic risk after the event may be expressed as:

$$
\beta_{i}^{1}=\rho_{i, m}^{1} \frac{\sigma_{i}^{1}}{\sigma_{m}^{1}}=\left(\rho_{i, m}^{0}+\Delta \rho_{i, m}\right) \frac{\sigma_{i}^{1}}{\sigma_{m}^{1}}=\beta_{i}^{0}+\Delta \beta_{i} .
$$

Reordering we obtain the equation for the change in the relative standard deviation:

$$
\Delta \frac{\sigma_{i}}{\sigma_{m}}=\frac{\sigma_{i}^{1}}{\sigma_{m}^{1}}-\frac{\sigma_{i}^{0}}{\sigma_{m}^{0}}=\frac{\beta_{i}^{0}+\Delta \beta_{i}}{\rho_{i, m}^{0}+\Delta \rho_{i, m}}-\frac{\beta_{i}^{0}}{\rho_{i, m}^{0}} .
$$

\section{Results}

As indicated above, 185 estimations were carried out using a sample of 241 trading days symmetrically set around the securitization registry date with the CNMV. Using event study methodology, the analysis calculated the mean for each of the estimated 
coefficients in equations (5) and (6). In order to test whether this mean is significantly different from zero we first use a conventional parametric test, the " $t$ " test. Since the validity of this test depends on the assumption of normality, which is infringed in this case, the analysis is completed by using a non-parametric test. This test is known as the Wilcoxon test (signed rank test) for the median, which is more effective when there is no normality. The results are completed with the number and percentage of the coefficients which are significantly different from zero at the $10 \%$ significance level.

The results are shown in Table 3 below. Given that the results for the different windows do not differ substantially, we only comment in depth on the results for the $+/-20$ window, since these were fairly representative, even though this table shows all of the values for all of the windows.

Table 3. Results for registry dates (Ibex-35)

\begin{tabular}{|c|c|c|c|c|c|c|c|}
\hline \multicolumn{3}{|c|}{ Window $+/-5$} & \multicolumn{3}{|c|}{ Wilcoxon } & \multicolumn{2}{|c|}{ Coefs sig $10 \%$} \\
\hline & Mean est. & t-statistic & p-val & Signed rank & p-val & Number & Percentage \\
\hline$\beta_{0}$ & -0.046375 & -5.690 & 0.000 & 5.280 & 0.000 & 49 & 26.49 \\
\hline$\beta_{1}$ & 0.842085 & 17.727 & 0.000 & 11.346 & 0.000 & 146 & 78.92 \\
\hline$\beta_{2}$ & 0.003985 & 1.985 & 0.049 & 0.725 & 0.468 & 28 & 15.14 \\
\hline$\beta_{3}$ & 0.002455 & 1.251 & 0.212 & 1.696 & 0.090 & 75 & 40.54 \\
\hline$\alpha_{0}$ & 0.593823 & 5.739 & 0.000 & 11.722 & 0.000 & 138 & 74.59 \\
\hline$\alpha_{1}$ & 0.226666 & 14.292 & 0.000 & 11.246 & 0.000 & 168 & 90.81 \\
\hline$\alpha_{2}$ & 0.542979 & 19.159 & 0.000 & 10.708 & 0.000 & 147 & 79.46 \\
\hline$\beta$ & 0.842085 & & & & & & \\
\hline$\Delta \beta$ & 0.02455 & & & & & & \\
\hline \multicolumn{3}{|c|}{ Window $+/-10$} & \multicolumn{3}{|c|}{ Wilcoxon } & \multicolumn{2}{|c|}{ Coefs sig 10\% } \\
\hline & Mean est. & t-statistic & p-val & Signed rank & p-val & Number & Percentage \\
\hline$\beta_{0}$ & -0.046564 & -5.706 & 0.000 & 5.358 & 0.000 & 49 & 26.5 \\
\hline$\beta_{1}$ & 0.839062 & 17.468 & 0.000 & 11.283 & 0.000 & 146 & 78.9 \\
\hline$\beta_{2}$ & $2.55 \mathrm{E}-04$ & 0.722 & 0.471 & 0.236 & 0.814 & 33 & 17.8 \\
\hline$\beta_{3}$ & 0.001489 & 1.512 & 0.132 & 1.979 & 0.048 & 73 & 39.5 \\
\hline$\alpha_{0}$ & 0.564623 & 5.656 & 0.000 & 11.708 & 0.000 & 131 & 70.8 \\
\hline$\alpha_{1}$ & 0.228713 & 14.334 & 0.000 & 11.335 & 0.000 & 164 & 88.7 \\
\hline$\alpha_{2}$ & 0.562143 & 20.753 & 0.000 & 10.996 & 0.000 & 148 & 80.0 \\
\hline$\beta$ & 0.839062 & & & & & & \\
\hline$\Delta \beta$ & 0.02978 & & & & & & \\
\hline \multicolumn{3}{|c|}{ Window $+/-20$} & \multicolumn{3}{|c|}{ Wilcoxon } & \multicolumn{2}{|c|}{ Coefs sig 10\% } \\
\hline & Mean est. & t-statistic & p-val & Signed rank & p-val & Number & Percentage \\
\hline$\beta_{0}$ & -0.045037 & -5.500 & 0.000 & 5.087 & 0.000 & 52 & 28.1 \\
\hline$\beta_{1}$ & 0.84357 & 17.589 & 0.000 & 11.338 & 0.000 & 147 & 79.5 \\
\hline$\beta_{2}$ & 2.29E-05 & 0.308 & 0.759 & 0.758 & 0.448 & 57 & 30.8 \\
\hline$\beta_{3}$ & 0.000644 & 1.224 & 0.223 & 1.729 & 0.084 & 76 & 41.1 \\
\hline$\alpha_{0}$ & 0.609594 & 5.715 & 0.000 & 11.714 & 0.000 & 133 & 71.9 \\
\hline$\alpha_{1}$ & 0.228367 & 14.259 & 0.000 & 11.357 & 0.000 & 166 & 89.7 \\
\hline$\alpha_{2}$ & 0.537521 & 18.986 & 0.000 & 10.692 & 0.000 & 143 & 77.3 \\
\hline$\beta$ & 0.84357 & & & & & & \\
\hline$\Delta \beta$ & 0.02576 & & & & & & \\
\hline
\end{tabular}


End of Table 3

\begin{tabular}{cccccccc}
\hline \multicolumn{2}{c}{ Window+-30 } & \multicolumn{3}{c}{ Wilcoxon } & \multicolumn{2}{c}{ Coefs sig 10\% } \\
\hline & Mean est. & t-statistic & p-val & Signed rank & p-val & Number & Percentage \\
\hline$\beta_{0}$ & -0.045084 & -5.570 & 0.000 & 5.160 & 0.000 & 47 & 25.4 \\
\hline$\beta_{1}$ & 0.846527 & 17.545 & 0.000 & 11.305 & 0.000 & 145 & 78.4 \\
\hline$\beta_{2}$ & $7.98 \mathrm{E}-06$ & 0.277 & 0.782 & 0.606 & 0.545 & 60 & 32.4 \\
\hline$\beta_{3}$ & 0.000415 & 1.124 & 0.263 & 1.643 & 0.101 & 79 & 42.7 \\
\hline$\alpha_{0}$ & 0.564773 & 5.542 & 0.000 & 11.698 & 0.000 & 131 & 70.8 \\
\hline$\alpha_{1}$ & 0.230451 & 14.545 & 0.000 & 11.393 & 0.000 & 167 & 90.3 \\
\hline$\alpha_{2}$ & 0.563521 & 20.821 & 0.000 & 10.985 & 0.000 & 145 & 78.4 \\
\hline$\beta$ & 0.846527 & & & & & \\
\hline$\Delta \beta$ & 0.0249 & &
\end{tabular}

Notes: The estimated model is

$\mathrm{R}_{i, t}=\beta_{i, 0}+\beta_{i, 1} \mathrm{R}_{m, t}+\beta_{i, 2}\left(\mathrm{~T}_{1}-\mathrm{t}\right)\left(\mathrm{t}-\mathrm{T}_{2}\right) \mathrm{D}_{1, t} \mathrm{R}_{m, t}+\beta_{i, 3}\left[\left(\mathrm{t}-\mathrm{T}_{1}\right) \mathrm{D}_{1, t}+\left(\mathrm{T}_{2}-\mathrm{T}_{1}\right) \mathrm{D}_{2, t}\right] \mathrm{R}_{m, t}+\varepsilon_{i, t}$

for the mean and $\mathrm{h}_{i, t}=\alpha_{i, 0}+\alpha_{i, 1} \varepsilon_{i, t}{ }^{2}+\alpha_{i, 2} \mathrm{~h}_{i, t-1}$ for the conditional variance. The estimations were carried out for 185 securitizations using a sample of 241 trading days symmetrically set around the securitization registry date in accordance with event analysis methodology for windows of 10,20,40 and 60 days. The results included are the mean for each of the estimated coefficients in the previous equations for 185 regressions, the conventional parametric " $t$ " test and the non-parametric Wilcoxon signed rank test in order to test the significance of the mean. The results are completed with the number and percentage of the coefficients which are significantly different from zero at the $10 \%$ significance level.

The parameters that measure the possible change in the systematic risk are significantly different from zero in 57 cases for $\beta_{2}$ and in 76 cases for $\beta_{3}$. The changes in the systematic risk measured within these parameters are not large enough to obtain a mean which is significantly different from zero in the case of $\beta_{2}$, but they are with respect to $\beta_{3}$.

With respect to the $\operatorname{GARCH}(1,1)$ equation, $90 \%$ of $\alpha_{1}$ values and $77.3 \%$ of $\alpha_{2}$ are significant, which confirms the need to model the conditional variance.

The mean of estimated coefficients $\beta_{1}$ before the event window is 0.843 . The mean of coefficients $\beta_{2}$ is positive $\left(2.29 \times 10^{-5}\right)$ but not significant, which means that the evolution of the systematic risk during the event window follows a linear trend. At the end of the window, the systematic risk reaches a maximum of 0.869 (Fig. 1). This evolution is the consequence of having obtained a significant mean value for $\beta_{3}$ of 0.0006 . Hence, the mean change in the systematic risk within the window is 0.0257 .

To a certain extent, the choice of the window is arbitrary. We assumed that the response of stock prices to securitization announcements ${ }^{5}$, during and after the event period, completely reflects the economic impact of securitizations on the issuing bank's systematic risk. Since we do not know the period that takes in the complete market reaction to these events, we carry out estimations for periods of 10, 20,40 and 60 days. The results are similar for all of the windows. Therefore, even if the daily change in the systematic risk during the window differs in function of its size, the post-event beta resulting from the accumulated change is highly similar in all four cases: $0.866,0.868,0.869$ and 0.871 for the windows of $11,21,41$ and 61 days respectively.

${ }^{5}$ The date when securitization is deemed to have been announced in the market is that which is registered with the CNMV. 


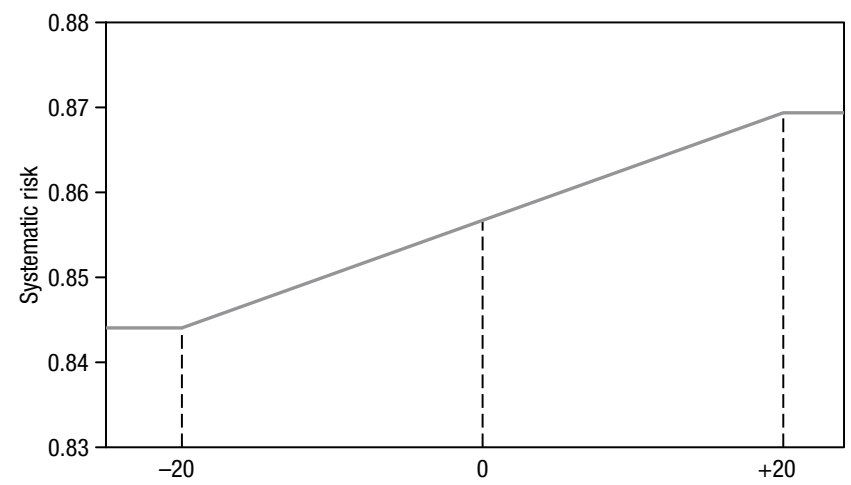

Fig. 1. Systematic risk (+/-20 window)

Note: Figure 1 refers to the results in Table 3 for the $+/-20$ window. The window shows the evolution of systematic risk within the event window for the set of 185 securitizations on and around the registry date.

The results of this analysis confirm a linear increase in the systematic risk of the Spanish banks during the event window. Initially, given that securitization is a mechanism that facilitates risk transfer, this result might seem strange. However, risk transmission can be practically non-existent when the tail risk of the senior tranches falls below the degree of default risks included in the first-loss tranches retained by the originator. In addition, taking into account the indirect effect of the securitization, the post-event systematic risk increases when the bank reinvests in riskier assets. This scenario is fairly likely in the Spanish market since banks were permissive in awarding credit and the requisites and regulations became more relaxed prior to the crisis. The beta coefficient might also increase even when the reinvestment of the liquidity obtained via securitization went towards a more highly diversified portfolio, if the pre-event systematic risk was lower than 1 as was the case of the sample used in this analysis $\left(\beta_{1}=0.843\right)$. The more highly diversified the bank's portfolio, the closer its returns will be to those of the market portfolio and its beta to 1 . In addition, the systematic risk might rise because the liquidity obtained from securitization is used to redistribute the capital structure. This could be in the form of paying greater dividends, or the repurchase of the company's own shares, which normally leads to an increase in bank leverage, augmenting risk.

Once the levels of return have been normalized, equation (7) is estimated and the results are given in Table 4. If we focus on the results for the $+/-20$ window it may be observed that there is a significant increase in the correlations, given that the pre-event correlation is 0.534 and increases to 0.021 at the end of the event window. Hence, it may be concluded that an increase in beta, on average, is due to an increase in the correlations.

Finally, equation (10) allows us to quantify the part of the increase in beta which is due to the standard deviation of the banks in relation to the market. The results obtained for the relative standard deviation $\left(\Delta \frac{\sigma_{i}}{\sigma_{m}}=-0.0135\right)$ indicate that the whole of the increase in beta is due to an increase in the correlations between the banks and the market. This means that the increase in beta that occurs as the result of securitization gives rise to an 
Table 4. Results for registry dates (Ibex-35). Normalized

\begin{tabular}{|c|c|c|c|c|c|c|c|}
\hline \multicolumn{3}{|c|}{ Window $+/-5$} & \multicolumn{3}{|c|}{ Wilcoxon } & \multicolumn{2}{|c|}{ Coefs sig $10 \%$} \\
\hline & Mean est. & t-statistic & p-val & Signed rank & p-val & Number & Percentage \\
\hline$\rho_{0}$ & -0.023581 & -5.322 & 0.000 & 5.316 & 0.000 & 41 & 22.16 \\
\hline$\rho_{1}$ & 0.534803 & 20.877 & 0.000 & 11.454 & 0.000 & 145 & 78.38 \\
\hline$\rho_{2}$ & 0.002393 & 1.782 & 0.076 & 0.599 & 0.549 & 29 & 15.68 \\
\hline$\rho_{3}$ & 0.001726 & 1.738 & 0.084 & 1.471 & 0.141 & 61 & 32.97 \\
\hline$\alpha_{0}$ & 0.156312 & 11.138 & 0.000 & 11.781 & 0.000 & 129 & 69.73 \\
\hline$\alpha_{1}$ & 0.215355 & 14.364 & 0.000 & 11.269 & 0.000 & 157 & 84.86 \\
\hline$\alpha_{2}$ & 0.552453 & 22.923 & 0.000 & 11.393 & 0.000 & 141 & 76.22 \\
\hline$\rho$ & 0.534803 & & & & & & \\
\hline$\Delta \rho$ & 0.01726 & & & & & & \\
\hline \multicolumn{2}{|c|}{ Window $+/-10$} & & \multicolumn{3}{|c|}{ Wilcoxon } & \multicolumn{2}{|c|}{ Coefs sig $10 \%$} \\
\hline & Mean est. & t-statistic & p-val & Signed rank & p-val & Number & Percentage \\
\hline$\rho_{0}$ & -0.023906 & -5.326 & 0.000 & 5.313 & 0.000 & 49 & 26.5 \\
\hline$\rho_{1}$ & 0.53437 & 20.945 & 0.000 & 11.437 & 0.000 & 149 & 80.5 \\
\hline$\rho_{2}$ & $2.03 \mathrm{E}-04$ & 0.840 & 0.402 & 0.078 & 0.938 & 36 & 19.5 \\
\hline$\rho_{3}$ & 0.000953 & 1.916 & 0.057 & 2.003 & 0.045 & 58 & 31.4 \\
\hline$\alpha_{0}$ & 0.155979 & 10.595 & 0.000 & 11.782 & 0.000 & 131 & 70.8 \\
\hline$\alpha_{1}$ & 0.210654 & 14.427 & 0.000 & 11.182 & 0.000 & 155 & 83.8 \\
\hline$\alpha_{2}$ & 0.548763 & 21.778 & 0.000 & 11.186 & 0.000 & 140 & 75.7 \\
\hline$\rho$ & 0.53437 & & & & & & \\
\hline$\Delta \rho$ & 0.01906 & & & & & & \\
\hline \multicolumn{2}{|c|}{ Window $+/-20$} & & \multicolumn{3}{|c|}{ Wilcoxon } & \multicolumn{2}{|c|}{ Coefs sig $10 \%$} \\
\hline & Mean est. & t-statistic & p-val & Signed rank & p-val & Number & Percentage \\
\hline$\rho_{0}$ & -0.023129 & -5.164 & 0.000 & 5.064 & 0.000 & 47 & 25.4 \\
\hline$\rho_{1}$ & 0.534802 & 21.136 & 0.000 & 11.464 & 0.000 & 149 & 80.5 \\
\hline$\rho_{2}$ & $4.11 \mathrm{E}-05$ & 0.808 & 0.420 & 0.097 & 0.922 & 57 & 30.8 \\
\hline$\rho_{3}$ & 0.000527 & 1.976 & 0.050 & 1.965 & 0.049 & 69 & 37.3 \\
\hline$\alpha_{0}$ & 0.152371 & 11.338 & 0.000 & 11.781 & 0.000 & 130 & 70.3 \\
\hline$\alpha_{1}$ & 0.219172 & 14.140 & 0.000 & 11.209 & 0.000 & 155 & 83.8 \\
\hline$\alpha_{2}$ & 0.539593 & 20.756 & 0.000 & 11.027 & 0.000 & 146 & 78.9 \\
\hline$\rho$ & 0.534802 & & & & & & \\
\hline$\Delta \rho$ & 0.02108 & & & & & & \\
\hline \multicolumn{2}{|c|}{ Window $+/-30$} & & \multicolumn{3}{|c|}{ Wilcoxon } & \multicolumn{2}{|c|}{ Coefs sig $10 \%$} \\
\hline & Mean est. & t-statistic & $\mathrm{p}$-val & Signed rank & p-val & Number & Percentage \\
\hline$\rho_{0}$ & -0.024672 & -5.624 & 0.000 & 5.317 & 0.000 & 49 & 26.5 \\
\hline$\rho_{1}$ & 0.538938 & 21.153 & 0.000 & 11.511 & 0.000 & 147 & 79.5 \\
\hline$\rho_{2}$ & $4.98 \mathrm{E}-06$ & 0.282 & 0.778 & 0.278 & 0.781 & 52 & 28.1 \\
\hline$\rho_{3}$ & 0.000298 & 1.596 & 0.112 & 1.414 & 0.158 & 71 & 38.4 \\
\hline$\alpha_{0}$ & 0.146717 & 11.754 & 0.000 & 11.789 & 0.000 & 133 & 71.89 \\
\hline$\alpha_{1}$ & 0.227509 & 14.773 & 0.000 & 11.379 & 0.000 & 159 & 85.95 \\
\hline$\alpha_{2}$ & 0.542522 & 22.191 & 0.000 & 11.282 & 0.000 & 141 & 76.22 \\
\hline$\rho$ & 0.538938 & & & & & & \\
\hline$\Delta \rho$ & 0.01788 & & & & & & \\
\hline
\end{tabular}

Notes: The estimated model is

$\tilde{\mathrm{R}}_{i, t}=\rho_{i, 0}+\rho_{i, 1} \tilde{\mathrm{R}}_{m, i, t}+\rho_{i, 2}\left(\mathrm{~T}_{1}-\mathrm{t}\right)\left(\mathrm{t}-\mathrm{T}_{2}\right) \mathrm{D}_{1, t} \tilde{\mathrm{R}}_{m, i, t}+\rho_{i, 3}\left[\left(\mathrm{t}-\mathrm{T}_{1}\right) \mathrm{D}_{1, t}+\left(\mathrm{T}_{2}-\mathrm{T}_{1}\right) \mathrm{D}_{2, t}\right] \tilde{\mathrm{R}}_{m, i, t}+\varepsilon_{i, t}$ for the mean and $\mathrm{h}_{i, t}=\alpha_{i, 0}+\alpha_{i, 1} \varepsilon_{i, t}{ }^{2}+\alpha_{i, 2} \mathrm{~h}_{i, t-1}$ for the conditional variance. The procedure is the same as described in Table 3 . 
increase in bank correlations. At the same time, there is a slight reduction in the specific risk for each entity, as a result of a small improvement in their portfolio diversification. In light of these findings, it may be affirmed that securitization leads to an increase in the overall or systemic risk within the Spanish financial system.

All these results hold when using the IGBM rather than the Ibex-35 as the market portfolio indicator.

\section{Conclusions}

Using a sample of 185 traditional securitizations issued by 14 banks operating in the Spanish market between 1993 and 2010, this analysis finds that securitization has a positive impact on the issuing entities' systematic risk and on the systemic risk within the whole of the Spanish financial system. The econometric study used event analysis that allowed systematic risk to change gradually within the event window.

The results show that securitization has a positive impact on the systematic risk of Spanish banks when the reference point used is this date when the securitization was registered with the CNMV. The banks' systematic risk increases from the start of the event window and follows a linear function until reaching its highest post-event risk level. This result is highly relevant since there is a widely-held belief that the originator banks aim to use securitization to reduce their exposition to risk.

The increase in the systematic risk is consistent with the predominant securitization model used in Spain, "originate to hold". There is, therefore, no real transfer of risk since the final loss of the portfolio is lower than the first loss tranche. From the point of view of the indirect effect, the increase in the systematic risk might be caused by the reinvestment of the liquidity obtained from securitization in products of lower credit quality, stimulated in recent years by the expansion in the availability of credit. However, the decomposition of the beta coefficient shows that the increase in the systematic risk is explained by an increase in the correlation between the originators' returns and the market in spite of the fact that the relative standard deviation for each entity declines on average. Hence, this breakdown allows us to affirm that securitization, from the point of view of the indirect effect, improves the diversification of the portfolio of issuing entities.

Our results are consistent with those from other studies that highlight that the credit risk transfer has important effects on bank risk. In general terms it may be affirmed that the results of this study, with respect to the business of securitization in Spain, are consistent with those obtained in previously published analyses by authors such as Udhe and Michalak (2010), Lockwood et al. (1996), Franke and Krahnen (2006), Hänsel and Krahnen (2007), and Nijskens and Wagner (2011).

This work has analysed one measure of risk, systematic risk, which is highly relevant for today's intensely competitive stock markets, given that, in accordance with the idea of stock price equilibrium, it is this risk which is the main determinant of price. Further, it has been proved that this increase in systematic risk creates greater risk within the financial system as a whole, that is, greater systemic risk. 
Finally, it should be highlighted that this work has certain informational consequences with respect to relevant collectives. For external or future investors, changes in systematic risk are fundamental indicators orienting portfolio readjustment; for the portfolio managers of the originators who are continually making adjustments to their financial structure; and, logically, for the regulators for whom this information might help to focus their control mechanisms, not simply on individual entities, but also on the market as a whole.

\section{References}

Acharya, V.; Yorulmazer, T. 2007. Too many to fail - an analysis of time-inconsistency in bank closure policies, Journal of Financial Intermediation 16(1): 1-31.

http://dx.doi.org/10.1016/j.jfi.2006.06.001

Association for Financial Markets in Europe (AFME). 2011. Securitisation data report. Q2.

Calmes, C.; Théoret, R. 2010. The impact of off-balance - sheet activities on banks returns: an application of the ARCH-M to Canadian data, Journal of Banking \& Finance 34(7): 1719-1728. http://dx.doi.org/10.1016/j.jbankfin.2010.03.017

Cardone-Riportella, C.; Samaniego-Medina, R.; Trujillo-Ponce, A. 2010. What drives bank securitisation? The Spanish experience, Journal of Banking \& Finance 34: 2639-2651.

http://dx.doi.org/10.1016/j.jbankfin.2010.05.003

Catarineu, E.; Pérez, D. 2008. La titulización de activos por parte de las entidades de crédito: el modelo español en el contexto internacional y su tratamiento desde el punto de vista de la regulación prudencial [Securitization of assets by credit institutions: the Spanish model in the international context and its treatment from the point of view of prudential regulation], Estabilidad Financiera 14: 89-121.

Cyree, K. B.; DeGennaro, R. P. 2002. A generalized method for detecting abnormal returns and changes in systematic risk, Review of Quantitative Finance and Accounting 19: 399-416.

http://dx.doi.org/10.1023/A:1021162208290

DeMarzo, P. M. 2005. The pooling and tranching of securities: a model of informed intermediation, Review of Financial Studies 18(1): 1-35. http://dx.doi.org/10.1093/rfs/hhi008

Douglas, W. D.; Raghuram, G. R. 2009. The credit crisis: conjectures about causes and remedies, American Economic Review 99(2): 606-610. http://dx.doi.org/10.1257/aer.99.2.606

Elsinger, H.; Lehar, A.; Summer, M. 2006. Using market information for banking system risk assessment, International Journal of Central Banking 2(1): 137-165.

Farhi, E.; Tirole, J. 2009. Leverage and the central banker's put, American Economic Review 99(2): 589-593. http://dx.doi.org/10.1257/aer.99.2.589

Franke, G.; Krahnen, J. P. 2006. Default risk sharing between banks and markets: the contribution ofcollateralized debt obligations, in: Carey, M.; Stulz, R. M. (Eds.). The risks of financial institutions. Chicago: University of Chicago Press, 603-633. http://dx.doi.org/10.1257/aer.99.2.589

Hänsel, D. N.; Krahnen, J. P. 2007. Does credit securitization reduce bank risk? Evidence from the European CDO market, Working Paper [online], [cited December 2012]. SSRN. Available from Internet: http://ssrn.com/abstract $=967430$

Instefjord, N. 2005. Risk and hedging: do credit derivates increase bank risk? Evidence from the European CDO market, Journal of Banking \& Finance 29(2): 333-345.

http://dx.doi.org/10.1016/j.jbankfin.2004.05.008

Jiangli, W.; Pritsker, M.; Paupach, P. 2007. Banking and securitization, Working Paper. FDIC, Federal Reserve Board and Deutsche Bundesbank. 
Keys, B.; Mukherjee, T.; Seru, A.; Vig, V. 2010. Did securitization lead to lax screening? Evidence from subprime loans, Quarterly Journal of Economics 125(1): 307-362.

http://dx.doi.org/10.1162/qjec.2010.125.1.307

Le, H. T. T.; Narayanan, R. P.; Van Vo, L. 2015. Has the effect of asset securitization on bank risk taking behaviour changed?, Journal of Financial Services Research 49(1): 39-64. http://dx.doi.org/10.1007/s10693-015-0214-1

Leland, H. E. 2007. Financial synergies and the optimal scope of the firm: implications for mergers, spinoffs, and structured finance, Journal of Finance 62(2): 765-807.

http://dx.doi.org/10.1111/j.1540-6261.2007.01223.x

Lockwood, L. J.; Rutherford, R. C.; Herrera, M. J. 1996. Wealth effects of asset securitization, Journal of Banking \& Finance 20(January): 151-164.

http://dx.doi.org/10.1016/0378-4266(94)00101-4

López-Andión, C.; Iglesias-Casal, A.; López-Penabad, M. C.; Maside-Sanfiz, J. M. 2015. The solvency of financial institutions in Spain: lessons from securitization, Applied Economics 47(44): 4741-4753. http://dx.doi.org/10.1080/00036846.2015.1034841

López-Penabad, M. C.; López-Andión, C.; Iglesias-Casal, A.; Maside-Sanfiz, J. M. 2015. Securitization in Spain and the wealth effect for shareholders, International Review of Economic and Finance 37: 308-323. http://dx.doi.org/10.1016/j.iref.2014.12.003

Martínez-Solano, P; Yagüe-Guirao, J.; López-Martínez, F. 2009. Asset securitization: effects on value of banking institutions, The European Journal of Finance 15(2): 119-136.

http://dx.doi.org/10.1080/13518470802466188

Nijskens, R.; Wagner, W. 2011. Credit risk transfer activities and systemic risk: how banks became less risky individually but posed greater risks to the financial system at the same time, Journal of Banking and Finance 35: 1391-1398. http://dx.doi.org/10.1016/j.jbankfin.2010.10.001

Pinto, J. M. 2014. The economics of securitization: evidence from the European markets. Working Paper [online], [cited May 2015]. Available from Internet: http://ssrn.com/abstract=2425381 Purnanandam, A. 2009. Originate to distribute model and the subprime mortgage crisis, Review of Financial Studies 24(6): 1881-1915. http://dx.doi.org/10.1093/rfs/hhq106

Shin, H. S. 2009. Securitisation and financial stability, The Economic Journal 119: 309-332. http://dx.doi.org/10.1111/j.1468-0297.2008.02239.x

Uhde, A.; Michalak, T. C. 2010. Securitization and systematic risk in European banking: empirical evidence, Journal of Banking \& Finance 34: 3061-3077.

http://dx.doi.org/10.1016/j.jbankfin.2010.07.012

Wagner, W. 2009. Efficient asset allocations in the banking sector and financial regulation, International Journal of Central Banking 5(1): 75-95. 
Ana IGLESIAS-CASAL is a Lecturer in Quantitative Economics at the University of Santiago de Compostela (USC) (Spain). Her research interests are focused on econometrics methods, on banking and finance, with a particular emphasis on securitization. She obtained her PhD from the USC. Her research has been published in journals like International Review of Economics \& Finance and Applied Economics among others. She has gained recognition for six years of international-quality research from the national committee for the assessment of the research action (CNEAI).

Maria Celia LÓPEZ-PENABAD is a Lecturer in Finance at the USC (Spain). Her research interests are focused on banking and finance, with a particular emphasis mortgage markets and on securitization. She obtained her PhD from the USC. Her research has been published in journals like International Review of Economics \& Finance and Applied Economics among others. She has gained recognition for six years of international-quality research from the national committee for the assessment of the research action (CNEAI).

Carmen LÓPEZ-ANDIÓN is a Lecturer in Quantitative Economics at the USC (Spain). Her research interests are focused on econometrics methods, on banking and finance, with a particular emphasis on housing markets, mortgage markets and on securitization. She obtained her PhD from the USC. Her research has been published in journals like International Review of Economics \& Finance and Applied Economics among others.

José Manuel MASIDE-SANFIZ is a Lecturer in Accounting at the USC (Spain). Her research interests are focused on banking and finance, and on environmental accountancy. She obtained her PhD from the USC. His research has been published in journals like International Review of Economics \& Finance and Applied Economics among others. He has gained recognition for six years of international-quality research from the national committee for the assessment of the research action (CNEAI). 